\title{
Influence of limestone mineral addition in cements on the efficacy of SCMs in mitigating alkali-silica reaction assessed by accelerated mortar bar test
}

\author{
Marie Joshua Tapas Ph.D. \\ School of Civil and Environmental Engineering, University of Technology Sydney \\ 81 Broadway Ultimo, NSW 2007 Australia \\ Corresponding author: mariejoshua.tapas@uts.edu.au \\ Kirk Vessalas Ph.D. \\ School of Civil and Environmental Engineering, University of Technology Sydney \\ 81 Broadway Ultimo, NSW 2007 Australia \\ Email: kirk.vessalas@uts.edu.au \\ Paul Thomas Ph.D. \\ School of Mathematical and Physical Sciences, University of Technology Sydney \\ 81 Broadway Ultimo, NSW 2007 Australia \\ Email: paul.thomas@uts.edu.au \\ Prof. Vute Sirivivatnanon Ph.D. \\ School of Civil and Environmental Engineering, University of Technology Sydney \\ 81 Broadway Ultimo, NSW 2007 Australia \\ Email: vute.sirivivatnanon@uts.edu.au
}

\section{Abstract}

This study evaluates the effect of limestone mineral addition in cement on the efficacy of supplementary cementitious materials (SCMs) in mitigating alkali-silica reaction (ASR) using the accelerated mortar bar test (AMBT). Mortars with and without SCMs were prepared by substituting portion of $0 \%$ limestone GP cement with increasing amounts of limestone. Mortars with SCMs ( $25 \%$ fly ash or $65 \%$ slag) exhibit negligible expansion regardless of the limestone content in the binder while mortars without SCMs exhibit high and almost identical expansion for all limestone substitutions. The expansion results show that limestone does not aggravate ASR, has no detrimental effect on the efficacy of SCMs in ASR mitigation and likewise has no observable ASR mitigating properties under the test conditions. The calcium silicate hydrate (C-S-H) composition is not affected by the amount of limestone which suggests that limestone has no influence on the alkali uptake in the C-S-H. This is supported by the pore solution analysis results where SCMs (both fly ash and slag) have drastically reduced the pore solution alkali concentration over time, whereas, limestone substitution only resulted to alkali 

reduction equivalent to substitution (dilution). Moreover, the carboaluminate phases formed when limestone is present were observed to decompose under AMBT conditions and thus, their influence on ASR mitigation is not possible to discern from this study.

Keywords: alkali-silica reaction; fly ash; slag; limestone; carboaluminates

\section{Introduction}

Cement production results in substantial amount of carbon dioxide $\left(\mathrm{CO}_{2}\right)$ emissions. Calcination of limestone in order to produce cement clinker accounts for about $60 \%$ of $\mathrm{CO}_{2}$ emissions at a cement plant (Scrivener, John and Gartner, 2016). Addition of supplementary cementitious materials (SCMs), such as in the case of blended cements, has the potential to reduce the economic and environmental impact of cement-based construction materials. Most commonly used SCMs, fly ash and slag, are however industrial by-products and increasingly becoming scarce resources (Scrivener, John and Gartner, 2016).

The foreseen shortage of fly ash supply is fueled by the closure of coal-fired power plants in various parts of the world in favour of renewable sources of energy (Johnson and Chau, 2019, Nalbandian-Sugden, 2015). Australia is no exception with around one-third of its coal-fired power stations closed during 2012-2017, with remaining expected to close as well in the coming decades (Burke, Best and Jotzo, 2018). Coal-fired power stations pollute the environment heavily due to significant production of greenhouse gases that can lead to global warming (ECRC, 2017, Thomson, Huelsman and Ong, 2018). Increasing recycling of steel and introduction of more efficient steelmaking technologies also lowers the availability of slag. Currently, slag production is only about $5-10 \%$ of total cement production worldwide and is expected to further decrease in the coming years (Scrivener, Martirena, Bishnoi and Maity, 2018). Thus, there is a need to explore alternative materials for blending into cement.

Limestone is an abundant natural resource and its addition to cement offers a potential route to reducing the $\mathrm{CO}_{2}$ emissions associated with cement production through partial substitution. General Purpose (GP) cement is 

the most common commercially used cement in Australia and accounts for over $85 \%$ of the total cement market for production of concrete (Mohammadi and South, 2016). The current allowable mineral addition in the Australian Standard AS 3972 for Type GP cement is 7.5\%. Due to the potential environmental benefits of increased limestone addition, there is a drive to increase limestone content in Australian GP cement from 7.5\% to $12 \%$ (Mohammadi and South, 2016). Whereas, the effect of limestone on various properties of concrete has been widely investigated (Lollini, Redaelli and Bertolini, 2014, Mohammadi and South, 2016, Schmidt, Lothenbach, Romer, Neuenschwander and Scrivener, 2009, Tsivilis, Batis, Chaniotakis, Grigoriadis and Theodossis, 2000, Tsivilis, Tsantilas, Kakali, Chaniotakis and Sakellariou, 2003), its effect on the alkali-silica reaction (ASR) and on the efficacy of SCMs in mitigating ASR is still not fully understood.

ASR is a major durability issue and can occur in concrete if three factors are present: reactive silica in the aggregate, highly alkaline pore solution, and sufficient moisture. High alkali content pore solution facilitates dissolution of reactive silica phases in the aggregate. Dissolved silica in the pore solution then bind cations ( $\mathrm{Na}^{+}$, $\mathrm{K}^{+}$, and $\mathrm{Ca}^{2+}$ ) to form the ASR product (alkali calcium silicate hydrate gel) which can induce pressure build up, resulting in expansion, and eventual cracking of the concrete (Chatterji, 2005, Rajabipour, Giannini, Dunant, Ideker and Thomas, 2015).

The available literature on the effect of limestone addition on ASR is, however, limited and in disagreement. Limestone has been variously reported to have either no effect on ASR acting as an inert diluent (Tennis, Thomas and Weiss, 2011, Thomas, Delagrave, Blair and Barcelo, 2013) or to aid in ASR mitigation (Hooton, Nokken and Thomas, 2007, Rajbhandari, 2010). At the extreme, limestone has been reported to mitigate ASR more effectively than Class F fly ash (Turk, Kina and Bagdiken, 2017), while synergistic effects of limestone with fly ash have also been recently reported to result in better ASR mitigating properties (Wang, Wu and Mei, 2019), although, in the latter case the elevated $\mathrm{SiO}_{2}$ content of the limestone powder $(15.71 \%)$ may have played a role in mitigation. Purity of the limestone used is, therefore, critical in ensuring that mitigation observed in laboratory studies is due to the limestone and not other constituents. The Australian standard, for instance, requires only $75 \% \mathrm{CaCO}_{3}$ content in minerals to meet the criteria as suitable limestone mineral addition (AS 3972). 
The reported ability of limestone to mitigate ASR is largely attributed to cement dilution (Hooton, Nokken and Thomas, 2007, Rajbhandari, 2010), to limestone providing additional sites for nucleation resulting in microstructural densification (Arora, Sant and Neithalath, 2016, Matschei, Lothenbach and Glasser, 2007, Ramezanianpour and Hooton, 2014), and to the formation of monocarboaluminates when limestone is present in cement (Chen and Yang, 2013). Calcite $\left(\mathrm{CaCO}_{3}\right)$ present in limestone reacts with aluminate phases in the cement to form monocarboaluminates resulting in a denser microstructure and an increase in compressive strength (Bonavetti, Donza, Menendez, Cabrera and Irassar, 2003, Bonavetti, Rahhal and Irassar, 2001, Tennis, Thomas and Weiss, 2011, Thomas, Delagrave, Blair and Barcelo, 2013, Voglis, Kakali, Chaniotakis and Tsivilis, 2005). The reaction is limited, however, by the amount of alumina available to react with calcite and above a certain replacement level, excess limestone (calcite) may result in degradation of concrete properties (Ramezanianpour and Hooton, 2014, Scrivener, Martirena, Bishnoi and Maity, 2018). Excess limestone in cement acts as a diluent and therefore limestone replacements greater than $15 \%$ has been reported to result in reduction in strength (Dhir, Limbachiya, McCarthy and Chaipanich, 2007).

Given the relative uncertainty of the role of limestone in ASR mitigation, this study investigates the influence of limestone on the reactivity of a reactive aggregate and on the efficacy of SCMs in mitigating ASR using the accelerated mortar bar test (AMBT), AS 1141.60.1. The Australian test method AS 1141.60 .1 was shown to be a relatively good test method for classifying "slowly reactive" and "reactive" aggregates consistent with field performance (Sirivivatnanon, Mohammadi and South, 2016). The effect of limestone mineral addition and AMBT test conditions on the microstructure and composition of mortars and pastes are also investigated.

\section{Materials and Methods}

\section{Raw Materials}

All raw materials (cement, aggregate, SCMs, limestone) used in this study were sourced in Australia. The cement, limestone and SCMs were supplied by Cement Australia and the reactive greywacke aggregate was supplied by Cement Concrete and Aggregates Australia (CCAA), the peak body for the heavy construction 
materials industry in Australia. Oxide compositions of cements, SCMs, limestone and aggregate utilized in the study are shown in Table 1. The XRF equipment used was PHILIPS PW2400 XRF Rh end-window tube coupled with "SUPERQ" software. The total alkali content of the cement conventionally calculated as equivalent sodium oxide $\left[\% \mathrm{Na}_{2} \mathrm{O}_{\text {eq }}=\% \mathrm{Na}_{2} \mathrm{O}+\left(0.658 \times \% \mathrm{~K}_{2} \mathrm{O}\right)\right]$ is $0.54 \% \mathrm{Na}_{2} \mathrm{O}_{\text {eq }}$ which is less than the $0.60 \% \mathrm{Na}_{2} \mathrm{O}_{\text {eq }}$ cement alkali limit specified for Australian cements. Both fly ash and slag conform to Australian specifications, AS/NZS 3582.1 and AS 3582.2 respectively. Table 2 shows the mineralogical composition of reactive aggregate greywacke as determined by petrographic analysis. The petrographic examination was conducted in accordance with Australian Standards AS2758.1 (1985) and ASTM C-295 (1990) by the Department of Geology, University of Newcastle, Australia.

The ground limestone $(\mathrm{GL})$ used in this study was shown to be predominantly calcite $\left(\mathrm{CaCO}_{3}\right)$ by XRD with trace proportions of quartz also present (Fig. 1). XRD was carried out using a Bruker D8 Discover XRD. Diffraction patterns were collected in Bragg-Brentano mode using Cu Ka radiation (1.5418 $\AA$ ) in the range 5 to $70^{\circ} 2 \theta$ using a step size $0.04 \%$ second. Phases were identified using the ICDD PDF 4+ database. Instruments SDT-Q600 Simultaneous TGA/DSC. The analysis was performed in a nitrogen atmosphere, by heating from $23^{\circ} \mathrm{C}$ to $1000{ }^{\circ} \mathrm{C}$ and at a heating rate of $10^{\circ} \mathrm{C} / \mathrm{min}$. The weight loss curves obtained are shown in Fig. 2. The mineral-addition-free GP cement showed only $0.2 \%$ mass loss between $600-800{ }^{\circ} \mathrm{C}$ confirming the negligible amount of $\mathrm{CaCO}_{3}$ present. The $\mathrm{GL}$, on the other hand, registered a mass loss of about $43 \%$, which indicates that it is $98 \% \mathrm{CaCO}_{3}$. This is consistent with $43 \%$ loss of ignition (LOI) in Table 1 which corresponds to the release of carbon dioxide $\left(\mathrm{CO}_{2}\right)$ at higher temperatures.

\section{Accelerated Mortar Bar Test (AMBT)}

AMBT was conducted to evaluate the effect of substituting portion of the cement with limestone on 
by mass were prepared in accordance with AS 1141.60.1 (Standards Australia, 2014). Limestone substitution was carried out at $0 \%, 8 \%, 12 \%$ and $17 \%$ by mass of cement. The SCMs were used at the recommended replacement dosages: 25\% fly ash and 65\% slag (Standards Australia, 2015).

The specimens were prepared in $25 \times 25 \times 285 \mathrm{~mm}$ moulds with a gauge length of $250 \mathrm{~mm}$ then cured in $\geq 90 \% \mathrm{RH}$ $23 \pm 2{ }^{\circ} \mathrm{C}$ for 24 hours. After, the specimens were carefully de-moulded and put in a container filled with water. The container was then placed in an oven set at $80{ }^{\circ} \mathrm{C}$ for another 24 hours to allow the specimens to further cure. After which, zero hour length measurements were obtained using a horizontal comparator prior immersing the specimens in $1 \mathrm{M} \mathrm{NaOH}$ solution at $80{ }^{\circ} \mathrm{C}$ for 28 days. The mortar specimens were taken out of the storage solution at $1,3,7,10,14,21$, and 28 days for succeeding expansion measurements. The expansion limits of AS 1141.60.1 are listed in Table 4. The reliability of the Australian test method is discussed in the study of Sirivivatnanon et al. (Sirivivatnanon, Mohammadi and South, 2016).

\section{Analysis of ASR Gel and C-S-H Composition}

The mortar specimens were sectioned post-AMBT (after 28 days) to characterize the calcium silicate hydrate (C-S-H) and ASR gel composition. The mortar was cut using diamond saw (about $2 \mathrm{~mm}$ thickness) and then immersed in isopropanol for 5 days to remove free water (solvent exchange process) and prevent further reactions. The samples were then stored in a vacuum desiccator to prevent carbonation until analysed.

Polished sections were prepared for SEM-EDS analysis by subjecting the cut mortar sections to resin vacuum impregnation and polishing. Manual polishing was first carried out to ensure the surface is flat and remove any extra resin on the surface of the sample using sandpaper grades 500 and 1200 respectively. This was followed by automated polishing using MD Largo Struers discs lubricated with petrol and diamond spray as a polishing agent $(9 \mu \mathrm{m}, 3 \mu \mathrm{m}$ and $1 \mu \mathrm{m}$ particle sizes). After polishing, the samples were subjected to 2 minutes ultrasonic cleaning to remove polishing debris and then stored in a vacuum desiccator for at least 2 days to dry. All analysed samples were carbon-coated to prevent charging during SEM imaging. 

detector. Imaging was carried out in backscattered electron (BSE) mode with a $15 \mathrm{kV}$ accelerating voltage and $12.5 \mathrm{~mm}$ working distance. To ensure consistent beam current, $\mathrm{X}$-ray intensities from copper film placed on the metallic sample holder was measured before each measurement to obtain a target "system factor" by adjusting the spot size. A predefined list of elements $(\mathrm{O}, \mathrm{Na}, \mathrm{Mg}, \mathrm{Al}, \mathrm{Si}, \mathrm{P}, \mathrm{S}, \mathrm{Cl}, \mathrm{K}, \mathrm{Ca}, \mathrm{Ti}, \mathrm{Fe})$ was used for identification and quantification. The composition of C-S-H was measured by point EDS analysis on the hydration rims around the hydrated clinker to minimize intermixing with other phases. Minimum of 200 points were analysed per sample. The technique was based on the method of Rossen and Scrivener (Rossen and Scrivener, 2017).

192

Pore Solution Analysis of Blended Pastes

In order to investigate the effect of limestone, fly ash and slag on the pore solution alkali concentration, blended pastes with $25 \%$ replacement levels of the cementitious materials were prepared in sealed containers (200ml) at water to cementitious materials ratio of 0.47 . The sealed containers were stored in a temperature and humidity cabinet at $\geq 90 \% \mathrm{RH}, 23 \pm 2{ }^{\circ} \mathrm{C}$. Pore solution extractions were carried out at 28 days and 168 days using a compression testing machine and a force of $1000 \mathrm{kN}$. All extracted solutions were filtered using a $0.2 \mu \mathrm{m}$ membrane to remove solids and after which analysed using inductively coupled plasma optical emission spectroscopy (ICP-OES). ICP-OES analysis was carried out using Shimadzu ICPE-9000.

\section{Formation of carboaluminate phases and the effect of AMBT conditions on stability}

In order to show the effect of limestone on the phases (i.e. demonstrate the formation of carboaluminates in different paste systems when limestone is present) as well as determine the effect of AMBT conditions on the stability of carboaluminates, two sets of limestone blended pastes with mix composition based on the mortar test specimens (i.e. same cement, limestone, SCM and water proportions), were prepared in $50 \times 50 \times 50 \mathrm{~mm}$ moulds using an electric hand mixer and left to cure inside a temperature and humidity cabinet at $\geq 90 \% \mathrm{RH}$, 

conditions $\left(1 \mathrm{M} \mathrm{NaOH} 80^{\circ} \mathrm{C}\right)$ similar to the mortar bars.

215

The limestone blended pastes were taken out at 21 days and 56 days for phase and microstructural characterization using XRD and SEM. No drying technique was employed to preserve the integrity of the phases to optimum quality. The solvent exchange method using isopropanol, although generally accepted as the best method to arrest hydration, still affects the amount of hydrates (ettringite crystals, AFm, carboaluminates) (Snellings, Chwast, Cizer, Belie, Dhandapani, Durdzinski, Elsen, Haufe, Hooton, Patapy, Santhanam, Scrivener, Snoeck, Steger, Tongbo, Vollpracht, Winnefeld and Lothenbach, 2018). For XRD, the samples were analysed the same day they were taken out from storage. The blended pastes were powdered using mortar and pestle and then carefully loaded into the XRD sample holders, ensuring to not over press the surface to prevent preferred orientation. XRD patterns were obtained using Bruker D8 Discover XRD in Bragg-Brentano mode using Cu K $\alpha$ radiation (1.5418 ̊̊) from 5 to $70^{\circ} 2 \theta$ at a scan rate of $0.04 \%$ second. Phases were identified using the ICDD PDF 4+ database. To characterize the microstructure, the blended pastes were fractured for secondary electron (SE) SEM imaging. Similar to the XRD samples, hydration was not deliberately stopped for the SEM samples in order to minimize damage to the microstructure. The samples were also "fractured" only right before SEM imaging to lessen the possibility of carbonation. The "fractured surface" samples with size maximum of approximately $5 \mathrm{x}$ $5 \mathrm{~mm}(\mathrm{LxW})$ were directly mounted on metal stubs using carbon tape and coated with gold-palladium prior to SEM imaging to prevent charging. SEM imaging was carried out using Zeiss Supra 55VP SEM. Images were collected at $15 \mathrm{kV}$ accelerating voltage and $12.5 \mathrm{~mm}$ working distance.

\section{Results and Discussions}

\section{AMBT Expansion Results}

AMBT expansion results in Fig. 3 show all mortars without SCM exhibiting high degree of expansion. Mortars containing SCMs (25\%FA or $65 \% \mathrm{SL}$ ) show negligible expansion regardless of limestone substitution. Thus, the 
plot represents an average of 3 samples and as the error is too small $(\leq 0.01 \%)$, it is no longer reported as error bars. The AMBT expansion results are consistent with the work of Thomas et al. (Thomas, Delagrave, Blair and Barcelo, 2013) which showed that the expansion levels for Portland cement and Portland-limestone cement mixtures (12\% limestone addition) are almost identical for mixtures with the same type of SCM and replacement level and that the efficacy of cement replacement with Class F fly ash or slag cement does not appear to be influenced by the presence of $12 \%$ limestone in the cement. The expansion limits of 0.10 at 10 days and $0.3 \%$ at 21 days are based on AS 1141.60.1 which is the Australian standard for testing aggregate reactivity typically extended for assessing SCM efficacy (Sirivivatnanon, Hocking, Cheney and Rocker, 2019, Sirivivatnanon, Mohammadi and South, 2016). Australia, at present, has no dedicated standard for assessing SCM efficacy.

Adding SCMs (25\%FA or $65 \% \mathrm{SL}$ ) reduced the expansion to negligible levels independently of the limestone content. Thus, limestone has no detrimental effect on the ability of SCMs to mitigate ASR. The ability of SCMs to mitigate ASR has been widely investigated (Bickmore, Nagy, Gray and Brinkerhoff, 2006, Chappex and Scrivener, 2012, Chappex and Scrivener, 2013, Duchesne and Berube, 1994, Durand, Berard, Roux and Soles, 1990, Hong and Glasser, 1999, Kim, Olek and Jeong, 2015, Shafaatian, Akhavan, Maraghechi and Rajabipour, 2013, Thomas, 2013). The mitigating properties of SCMs are reported to be due to: 1) the products formed by SCM reactions resulting in microstructure densification and lower permeability, thereby retarding alkali ingress (Shafaatian, Akhavan, Maraghechi and Rajabipour, 2013), 2) modification of the calcium silicate hydrate (C-S-H) composition resulting in enhanced alkali binding capacity (Duchesne and Berube, 1994, Durand, Berard, Roux and Soles, 1990, Hong and Glasser, 1999, Kim, Olek and Jeong, 2015, Thomas, 2013) and 3) aluminium present in SCMs such as fly ash and slag suppressing ASR by inhibiting dissolution of reactive silica in aggregates (Bickmore, Nagy, Gray and Brinkerhoff, 2006, Chappex and Scrivener, 2012, Chappex and Scrivener, 2013).

Fig. 4 illustrates clearly that mortars with limestone and no SCM exhibit almost similar expansion regardless of the limestone content in the binder ( 0 to $17 \% \mathrm{GL}$ ). The observed nearly identical degree of expansion with increasing limestone content in mortars without SCMs suggests that whereas limestone $\left(\mathrm{CaCO}_{3}\right)$ does not aggravate ASR, under the conditions present during AMBT, limestone also appears to have no observable ASR mitigating properties. Whereas, cement limestone substitution is expected to result in reduced pore solution 

reportedly densifies the microstructure due to the formation of monocarboaluminates (Bonavetti, Rahhal and Irassar, 2001, Chen and Yang, 2013). The expansion results however suggest that it does not appear to contribute to ASR mitigation under the test conditions.

\section{Characterization of the Mortar Specimens Post-AMBT}

Fig. 5 shows the SEM images of cross-sectioned greywacke mortar specimens without SCM addition post 28 days AMBT (0\%GL, $8 \% \mathrm{GL}, 12 \% \mathrm{GL}$ and $17 \% \mathrm{GL})$. Extensive cracking can be observed in all mortars which is consistent with the high degree of expansion during AMBT. High magnification image of the ASR gel in the mortar with 12\%GL but no SCM shown in Fig. 5e appears similar to that reported in literature (Andreas Leemann, 2017, Fernandes, 2009, Leemann and Lothenbach, 2008). The gel is sandwiched between an aggregate particle that appears to have cracked and fully separated.

Table 3 tabulates corresponding EDS point locations 1 to 5 in Fig. $5 e$ which shows that the ASR gel contains a significant amount of calcium (Ca), silicon (Si), and sodium ( $\mathrm{Na}$ ). Si concentration in the ASR gel dominates at an average of $64 \%$, with notable concentrations of $\mathrm{Ca}$ and $\mathrm{Na}$ at approximately $17 \%$. Negligible amount of potassium (about 1\%) detected is consistent with other ASR gel studies in AMBT specimens (Gavrilenko, Amo, Perez and Garcia, 2007, Shafaatian, Akhavan, Maraghechi and Rajabipour, 2013). In contrast, ASR gel in concretes that underwent either concrete prism test or taken from structures damaged by ASR typically contain almost equivalent contents of $\mathrm{Na}$ and K (Andreas Leemann, 2017, Leemann, Katayama, Fernandes and Broekmans, 2016, Leemann and Merz, 2013, Thaulow, Jakobsen and Clark, 1996). The obtained average Ca/Si ratio and $(\mathrm{Na}+\mathrm{K}) / \mathrm{Si}$ ratio of the ASR gel is 0.26 and 0.29 respectively, which closely agrees with that reported in other studies (Andreas Leemann, 2017, Leemann, Katayama, Fernandes and Broekmans, 2016, Leemann and 

the available potassium in the pore solution of mortars without SCMs. This finding is consistent with the study of Golmakani and Hooton (Golmakani and Hooton, 2019) which reported that AMBT mortar bar pore solutions showed mainly sodium, with hardly any potassium. Likewise, this also supports the nearly identical expansion observed regardless of limestone substitution amount in mortars without SCMs. Due to the high alkali concentration of the $1 \mathrm{M} \mathrm{NaOH}$ storage solution, the dilution effect resulting from increasing levels of limestone substitution is not possible to detect by AMBT, confirming that AMBT is not a suitable method for assessing the effect of cement dilution (due to limestone substitution) on ASR and, hence, the influence of limestone content on ASR gel composition was not further investigated.

Fig. 6 shows the low magnification SEM images of the cross-sectioned greywacke AMBT specimens with SCM contents at recommended replacement levels: $0 \% \mathrm{GL}+25 \% \mathrm{FA}, 0 \% \mathrm{GL}+65 \% \mathrm{SL}, 17 \% \mathrm{GL}+25 \% \mathrm{FA}$ and $17 \% \mathrm{GL}+65 \% \mathrm{SL}$. The mortar specimens show no major cracking in the aggregate or paste which is consistent with negligible levels of expansion during AMBT. This result supports the high efficacy of SCMs in ASR mitigation independent of the amount of limestone present in the mortar. Minor cracks observed are likely due to the cutting process.

Some of the mortar specimens were subjected to SEM-EDS analysis post-AMBT to investigate the effect of limestone addition on C-S-H composition. Mortars without limestone (0\%GL) and with maximum limestone content $(17 \% \mathrm{GL})$ were chosen to better illustrate the effect of limestone. The EDS scatter plots in Fig. 7 show that the $\mathrm{Si} / \mathrm{Ca}$ and $\mathrm{Al} / \mathrm{Si}$ ratio of the $\mathrm{C}-\mathrm{S}-\mathrm{H}$ is comparable in mortars without SCMs for both $0 \% \mathrm{GL}$ and $17 \% \mathrm{GL}$. This agrees with the studies of C-S-H composition in ambient cured limestone blended cement pastes (AduAmankwah, Zajac, Stabler, Lothenbach and Black, 2017, Weerdt, Haha, Saout, Kjellsen, Justnes and Lothenbach, 2011). Adu-Amankwah et al. (Adu-Amankwah, Zajac, Stabler, Lothenbach and Black, 2017) reported that there was no observed significant change in the C-S-H Al/Si ratio with increasing limestone content. Likewise, it has been shown that the $\mathrm{Ca} / \mathrm{Si}$ ratio and $\mathrm{Al} / \mathrm{Si}$ ratio of $\mathrm{OPC}$ and $\mathrm{OPC}$-limestone blended pastes are similar and constant over time (Weerdt, Haha, Saout, Kjellsen, Justnes and Lothenbach, 2011). 

the amount of limestone present. The modification in C-S-H composition when SCMs are present is linked to increased alkali binding capacity in the C-S-H (Chappex and Scrivener, 2012, Hong and Glasser, 2002, L'Hôpital, Lothenbach, Scrivener and D.A.Kulik, 2016). Since C-S-H composition affects the ability to adsorb alkali (i.e. higher Si/Ca ratio, higher ability to bind alkali), comparable C-S-H composition for $0 \% \mathrm{GL}$ and $17 \% \mathrm{GL}$ mortars (without SCM or with SCM but same type and dosage) suggests that limestone content has no effect on the alkali binding capacity of the C-S-H. EDS spot analysis was carried out to investigate the effect of Si/Ca ratio on the alkali binding capacity of the C-S-H, however, the values obtained for the alkali contents of the C-S-H were too small to determine variation and are not reported. Nevertheless, the result of pore solution analysis of blended pastes in Fig. 8 demonstrates the effect of limestone, fly ash and slag replacement on pore solution alkali concentration.

Extracted pore solutions of blended pastes at 28 days and 168 days with equivalent replacement level (25\%) of cementitious materials (fly ash, slag and limestone) are shown in Fig. 8. The results show much lower alkali concentration in all pastes when SCMs are present and the reduction of total alkali ( $\mathrm{Na}$ and $\mathrm{K}$ ) is a function of the type of SCM. Fly ash clearly reduces the pore solution alkali concentration more than slag which is consistent with another study (Canham, Page and Nixon, 1987). Since 25\% SCM replacement does not have an identical effect on the pore solution alkali concentration, this indicates that the effect of SCM addition is more than just cement dilution. A similar trend was also observed for pore solutions extracted after 168 days (6 months). The strong pozzolanic reaction associated with higher amount of reactive silica in fly ash increases the amount of C$\mathrm{S}-\mathrm{H}$ formed with lower $\mathrm{Ca} / \mathrm{Si}$ ratio that are able to take up more alkalis. Further decrease in alkali concentration with time is also clearly observed. This indicates that the process of alkali binding is continuous with time as the SCM reacts in the paste.

Fig. 8 also clearly demonstrates alkali dilution induced by $25 \%$ limestone substitution. The decrease in the concentration of alkali cations with limestone substitution is consistent with that reported in another study where $50 \%$ limestone substitution resulted to $50 \%$ reduction in Na and $\mathrm{K}$ concentration (Schöler, Lothenbach, 
no capacity to continuously bind alkalis un like SCMs which showed decrease in alkali concentration as a function

of time. Moreover, a slight increase in the concentration of alkalis from 28 days to 168 days can be observed in both OPC and OPC-limestone blend with time consistent with what has been reported in several studies (Lothenbach, Saout, Gallucci and Scrivener, 2008, Vollpracht, Lothenbach, Snellings and Haufe, 2016, Weerdt, Haha, Saout, Kjellsen, Justnes and Lothenbach, 2011). Although part of the alkalis is bound in the C-S$\mathrm{H}$, the alkali concentration increases with time as alkalis continue to be released during the hydration of clinkers and as the volume of the liquid phase present decreases (Lothenbach, Saout, Gallucci and Scrivener, 2008).

\section{Effect of AMBT conditions on carboaluminates (blended cement pastes)}

XRD patterns in Figs. 9 and 10 confirm the formation of carboaluminates as well as the presence of ettringite crystals in the limestone blended cement pastes cured and aged in a temperature and humidity cabinet at $\geq 90 \% \mathrm{RH}, 23 \pm 2{ }^{\circ} \mathrm{C}$. Carboaluminates were not observed in cement pastes without limestone as expected. Fig. 9 shows that monocarboaluminate is the main carbonate phase present in cement-limestone pastes at age 21 and 56 days. The interest on 21 days is due to the test limits of AS 1141.60 .1 ( $0.3 \%$ expansion at 21 days). The curing was further extended to 56 days to determine the influence of age on the carboaluminate phases. A tiny peak due to the presence of hemicarboaluminate in cement-limestone pastes that is present at 21 days is observed to have disappeared at 56 days. This indicates that whereas, hemicarboaluminates form at early hydration, they slowly convert to the more stable monocarboaluminates over time as more carbonate ions become available in the pore solution (Adu-Amankwah, Zajac, Stabler, Lothenbach and Black, 2017, Ipavec, Gabrovgek, Vuk, Kaucic, Macek and Medenz, 2011). Formation of carboaluminates results in increased amount of hydrates and also indirectly stabilises ettringite leading to a decrease in porosity and more dense microstructure (Lothenbach, Saout, Gallucci and Scrivener, 2008). Formed ettringite slowly converts to monosulfoaluminate when there is insufficient gypsum in the system. When $\mathrm{CaCO}_{3}$ is present, monosulfoaluminate-monocarboaluminate transformation occurs, thereby providing new source of additional sulfate ions in the system resulting in the reprecipitation of ettringite (Bonavetti, Rahhal and Irassar, 2001). 
Fig. 10 shows the XRD patterns of cement-fly ash-limestone and cement-slag-limestone blends at 21 days. Hemicarboaluminate was observed as the main carbonate phase in the cement-slag-limestone blends, whereas, monocarboaluminate is the dominant carbonate phase in the cement-fly ash-limestone blends similar to that of plain cement. The difference in the dominant carbonate phase in blends with either fly ash or slag is consistent with that reported in previous studies (Adu-Amankwah, Zajac, Stabler, Lothenbach and Black, 2017, Weerdt, Haha, Saout, Kjellsen, Justnes and Lothenbach, 2011). It is possible that the high substitution levels of slag at $65 \%$ increased the aluminium sufficiently to favour the presence of hemicarboaluminate over monocarboaluminate. It has been reported that when the availability of aluminate is much higher than the availability of carbonate, hemicarboaluminate tends to be more stable (Ipavec, Gabrovgek, Vuk, Kaucic, Macek and Medenz, 2011, Whittaker, Zajac, Ben Haha, Bullerjahn and Black, 2014).

Fig. 11 show the effect of AMBT conditions on the limestone blended cement pastes at 21 and 56 days. In all cases, regardless of the presence or absence of SCMs, ettringite and carboaluminate peaks disappear which indicates that both phases are unstable under the test conditions. It is well established that ettringite is intrinsically unstable in cement pastes above $70{ }^{\circ} \mathrm{C}$ (Scrivener and Taylor, 1993, Shimada and Young, 2004, Taylor, Famy and Scrivener, 2001). Monocarboaluminates, on the other hand, are reported to be stable at temperatures $\leq 70{ }^{\circ} \mathrm{C}$, but decompose at temperatures $\geq 90^{\circ} \mathrm{C}$ (Matschei, Lothenbach and Glasser, 2007). This is in close agreement with the current study which clearly shows that carboaluminates decompose when exposed to $1 \mathrm{M} \mathrm{NaOH} 80^{\circ} \mathrm{C}$.

SEM images in Fig. 12 are in agreement with the observations from XRD. Whereas, the SEM images of the limestone blended cement pastes after 21 days at $\geq 90 \% \mathrm{RH} 23 \pm 2{ }^{\circ} \mathrm{C}$ show presence of ettringite crystals (needlelike morphology), the limestone blended pastes post 21 days exposure to $1 \mathrm{M} \mathrm{NaOH} 80^{\circ} \mathrm{C}$ confirm absence of ettringite crystals. SEM and XRD results therefore indicate that since AMBT conditions facilitate the decomposition of ettringite crystals and carboaluminates, their influence on ASR mitigation is not possible to assess using AMBT.

\section{.}


The accelerated mortar bar test (AMBT) expansion results show that limestone mineral addition up to $17 \%$ in cement has no detrimental effect on the ability of SCMs to mitigate ASR. The substitution of cement with either $25 \%$ fly ash or $65 \%$ slag showed sufficient capacity of the SCM to mitigate ASR regardless of limestone content in the binder. AMBT mortars without SCM show nearly identical levels of expansion regardless of limestone content in the binder which indicates that whereas limestone does not aggravate ASR, it also does not actively mitigate ASR like SCMs.

421

SEM-EDS analysis of the C-S-H phases in the mortars post-AMBT show that limestone does not modify the C-S-H composition. The increase in $\mathrm{Si} / \mathrm{Ca}$ and $\mathrm{Al} / \mathrm{Si}$ ratio of the $\mathrm{C}-\mathrm{S}-\mathrm{H}$ that occurs when $\mathrm{SCMs}$ are present results in better alkali uptake. Pore solution analysis of blended cement pastes with SCMs and limestone support this findings. The pore solution alkali concentration when SCMs are present continuously decreases over time whereas limestone substitution merely results in dilution. Limestone addition, therefore, does not change the alkali binding capacity of the C-S-H and therefore does not actively reduce the pore solution concentration like SCMs.

The ASR gel observed in the mortar without SCM is primarily composed of sodium, silicon and calcium. The negligible presence of potassium in the ASR gel indicates that the $1 \mathrm{M} \mathrm{NaOH}$ storage solution dominates the pore solution of the mortar. This indicates that AMBT is not a suitable method to assess the effect of alkali dilution, an expected effect of cement limestone substitution, due to the high concentrations of alkali available from the bath. Further, although carboaluminates were observed in $\geq 90 \% \mathrm{RH} 23 \pm 2{ }^{\circ} \mathrm{C}$ cured limestone cement pastes (which confirms that limestone is not inert in the system), their absence in pastes cured under AMBT conditions $\left(1 \mathrm{M} \mathrm{NaOH}\right.$ and $\left.80^{\circ} \mathrm{C}\right)$ indicate that these phases are unstable under these conditions and therefore do not contribute to microstructure densification. Thus, the influence of carboaluminates on ASR mitigation is not possible to assess by the AMBT method. 
mitigation, it also clearly brings about the limitations of AMBT - which is its inability to assess the effect of cement dilution as well the influence of carboaluminates on ASR mitigation. In order to fully investigate the influence of limestone on ASR, CPT tests need to be carried out as under the CPT testing conditions the alkali content of the concrete is finite and storage temperature is much lower $\left(38^{\circ} \mathrm{C}\right)$ which will inhibit dissolution of phases. Studies on the influence of limestone on ASR will be the subject of further investigation through CPT testing.

\section{Data Availability Statement}

450

Some or all data, models, or code that support the findings of this study are available from the corresponding author upon reasonable request.

453

Acknowledgements

This study is a part of University of Technology Sydney research funded through Australian Research Council

Research Hub for Nanoscience Based Construction Materials Manufacturing (NANOCOMM) with the support

of Cement Concrete and Aggregates Australia (CCAA). This work would also not have been possible without laboratory equipment provided by Laboratory of Construction Materials at EPFL Switzerland courtesy of Professor Karen Scrivener.

461

462

\section{References}

463

Adu-Amankwah, S., Zajac, M., Stabler, C., Lothenbach, B., and Black, L. (2017). "Influence of limestone on the hydration of ternary slag cements." Cem. Concr. Res., 100, 96109.http://dx.doi.org/10.1016/j.cemconres.2017.05.013

467 Andreas Leemann, T. K., Isabel Fernandes, Maarten A. T. M. Broekmans (2017). "Raman microscopy of alkalisilica reaction (ASR) products formed in concrete." Cem. Concr. Res., 102, 41- 

rate of quartz." Geochim. Cosmochim. Acta, 70, 290-305.https://doi.org/10.1016/j.gca.2005.09.017 Bonavetti, V., Donza, H., Menendez, G., Cabrera, O., and Irassar, E. F. (2003). "Limestone filler cement in low w/c concrete: A rational use of energy." Cem. Concr. Res., 33 865-871.https://doi.org/10.1016/S00088846(02)01087-6 Bonavetti, V., Rahhal, V., and Irassar, E. (2001). "Studies on the carboaluminate formation in limestone-filler blended cements." Cem. Concr. Res., 31, 853-859.https://doi.org/10.1016/S0008-8846(01)00491-4 Burke, P. J., Best, R., and Jotzo, F. (2018). "Closures of coal-fired power stations in Australia:Local unemployment effects." CCEP Working Paper 1809, Crawford School of Public Policy, The Australian National University. Related to the Control of Alkali-Silica Reaction." Cem. Concr. Res., 17, 839-844.https://doi.org/10.1016/00088846(87)90046-9 Chappex, T., and Scrivener, K. (2012). "Alkali fixation of C-S-H in blended cement pastes and its relation to alkali silica reaction." Cem. Concr. Res., 42, 1049-1054.https://doi.org/10.1016/j.cemconres.2012.03.010 Chappex, T., and Scrivener, K. (2012). "The influence of aluminium on the dissolution of amorphous silica and its relation to alkali silica reaction." Cem. Concr. Res., 42, 16451649.http://dx.doi.org/10.1016/j.cemconres.2012.09.009

491 Chappex, T., and Scrivener, K. (2013). "The Effect of Aluminum in Solution on the Dissolution of Amorphous Silica and its Relation to Cementitious Systems." J. Am. Ceram. Soc., 96(2), 592-597. https://doiorg.ezproxy.lib.uts.edu.au/10.1111/jace.12098 Chatterji, S. (2005). "Chemistry of alkali-silica reaction and testing of aggregates." Cem. Concr. Compos., 27, 788-795.https://doi.org/10.1016/j.cemconcomp.2005.03.005 

cements for use in concrete construction." Materials and Structures 459-473.https://doi.org/10.1617/s11527006-9143-7

501

Duchesne, J., and Berube, M. A. (1994). "The Effectiveness of Supplementary Cementing Materials in Suppressing Expansion Due to ASR: Another Look at the Reaction Mechanisms Part 2: Pore Solution Chemistry." Cem. Concr. Res., 24(2), 221-230.https://doi.org/10.1016/0008-8846(94)90047-7 Durand, B., Berard, J., Roux, R., and Soles, J. (1990). "Alkali-Silica Reaction: The Relation Between Pore Solution Characteristics and Expansion Test Results." Cem. Concr. Res., 20, 419428.https://doi.org/10.1016/0008-8846(90)90032-S ECRC (2017). "Environment and Communications References Committee-Retirement of coal fired power stations." $<$ https://www.aph.gov.au/Parliamentary Business/Committees/Senate/Environment and Communications/C oal_fired_power_stations/Final_Report>. Fernandes, I. (2009). "Composition of alkali-silica reaction products at different locations within concrete structures." Mater. Charact., 60, 655-668.http://dx.doi.org/10.1016/i.matchar.2009.01.011 Gavrilenko, E., Amo, D. G. d., Perez, B. C., and Garcia, E. G. (2007). "Comparison of ASR-gels in concretes against accelerated mortar bar test samples." Mag. Concr. Res., 59(7), 483-494.https://doiorg.ezproxy.lib.uts.edu.au/10.1680/macr.2007.59.7.483 Golmakani, F., and Hooton, R. D. (2019). "Impact of pore solution concentration on the accelerated mortar bar alkali-silica reactivity test." Cem. Concr. Res., 121, 72-80.https://doi.org/10.1016/j.cemconres.2019.02.008 Hong, S.-Y., and Glasser, F. P. (1999). "Alkali binding in cement pastes Part I. The C-S-H phase." Cem. Concr. Res., 29, 1893-1903.https://doi.org/10.1016/S0008-8846(99)00187-8 Hong, S.-Y., and Glasser, F. P. (2002). "Alkali sorption by C-S-H and C-A-S-H gels Part II. Role of alumina." Cem. Concr. Res., 32, 1101-1111.https://doi.org/10.1016/S0008-8846(02)00753-6 Hooton, R. D., Nokken, M., and Thomas, M. D. A. (2007). "Portland-Limestone Cement: State of the Art Report and Gap Analysis For CSA A 3000." University of Toronto Ipavec, A., Gabrovgek, R., Vuk, T., Kaucic, V., Macek, J., and Medenz, A. (2011). "Carboaluminate Phases Formation During the Hydration of Calcite-Containing Portland Cement." J. Am. Cer. Soc., 94(4), 1238-1242. 
Johnson, S., and Chau, K. (2019). "More U.S. coal-fired power plants are decommissioning as retirements

continue." Today in Energy, U.S. Energy Information Administration.

Kim, T., Olek, J., and Jeong, H. (2015). "Alkali-silica reaction: Kinetics of chemistry of pore solution and calcium hydroxide content in cementitious system." Cem. Concr. Res., 71, 36-

L'Hôpital, E., Lothenbach, B., Scrivener, K., and D.A.Kulik (2016). "Alkali uptake in calcium alumina silicate hydrate (C-A-S-H)." Cem. Concr. Res., 85, 122-136.http://dx.doi.org/10.1016/i.cemconres.2016.03.009 Leemann, A., Katayama, T., Fernandes, I., and Broekmans, M. A. T. M. (2016). "Types of alkali-aggregate reactions and the products formed." Constr. Mater., 169, 128-135.http://dx.doi.org/10.1680/jcoma.15.00059 Leemann, A., and Lothenbach, B. (2008). "The influence of potassium-sodium ratio in cement on concrete expansion due to alkali-aggregate reaction." Cem. Concr. Res., 38, 11621168.https://doi.org/10.1016/j.cemconres.2008.05.004 Leemann, A., and Merz, C. (2013). "An attempt to validate the ultra-accelerated microbar and the concrete performance test with the degree of AAR-induced damage observed in concrete structures." Cem. Concr. Res., 49, 29-37.http://dx.doi.org/10.1016/i.cemconres.2013.03.014 Lollini, F., Redaelli, E., and Bertolini, L. (2014). "Effects of portland cement replacement with limestone on the properties of hardened concrete." Cem. Concr. Compos., 46, 3240.http://dx.doi.org/10.1016/j.cemconcomp.2013.10.016 Lothenbach, B., Saout, G. L., Gallucci, E., and Scrivener, K. (2008). "Influence of limestone on the hydration of Portland cements." Cem. Concr. Res., 38, 848-860.https://doi.org/10.1016/j.cemconres.2008.01.002 Matschei, T., Lothenbach, B., and Glasser, F. P. (2007). "The role of calcium carbonate in cement hydration." Cem. Concr. Res., 37(4), 551-558.https://doi.org/10.1016/j.cemconres.2006.10.013

549 Matschei, T., Lothenbach, B., and Glasser, F. P. (2007). "Thermodynamic properties of Portland cement hydrates in the system $\mathrm{CaO}-\mathrm{Al}_{2} \mathrm{O}_{3}-\mathrm{SiO}_{2}-\mathrm{CaSO}_{4}-\mathrm{CaCO}_{3}-\mathrm{H}_{2} \mathrm{O}$." Cem. Concr. Res., 37, 13791410.https://doi.org/10.1016/j.cemconres.2007.06.002

552 Mohammadi, I., and South, W. (2016). "General purpose cement with increased limestone content in 

555-564.http://dx.doi.org/10.1016/i.conbuildmat.2016.04.071 Nalbandian-Sugden, H. (2015). "New regulatory trends: effects on coal-fired powerplants and coal demand." $C C C / 262$.

Rajabipour, F., Giannini, E., Dunant, C., Ideker, J., and Thomas, M. (2015). "Alkali-silica reaction: Current understanding of the reaction mechanisms and the knowledge gaps." Cem. Concr. Res., 76, 130146.http://dx.doi.org/10.1016/i.cemconres.2015.05.024 Rajbhandari, N. (2010). "Determining the Effect of Intergrinding Limestone with Portland Cement on the Durability of Concrete with and without SCM " Masters Thesis, The University of New Brunswick. Ramezanianpour, A. M., and Hooton, R. D. (2014). "A study on hydration, compressive strength, and porosity of Portland-limestone cement mixes containing SCMs." Cem. Concr. Compos., 51, 113.https://doi.org/10.1016/j.cemconcomp.2014.03.006 Rossen, J. E., and Scrivener, K. L. (2017). "Optimization of SEM-EDS to determine the C-A-S-H composition in matured cement paste samples." Mater. Charact., 123, 294306.https://doi.org/10.1016/j.matchar.2016.11.041 microstructural aspects of sulfate attack on ordinary and limestone blended Portland cements." Cem. Concr. Res., 39(12), 1111-1121.https://doi.org/10.1016/j.cemconres.2009.08.005 of SCM-blended Portland cements: A pore solution and isothermal calorimetry study." Cem. Concr. Res., 93, 71-82.https://doi.org/10.1016/j.cemconres.2016.11.013 Scrivener, K., Martirena, F., Bishnoi, S., and Maity, S. (2018). "Calcined clay limestone cements (LC3)." Cem. Concr. Res., 114, 49-56.https://doi.org/10.1016/j.cemconres.2017.08.017 Scrivener, K. L., John, V. M., and Gartner, E. M. (2016). "Eco-Efficient Cements: Potential, economically viable solutions for a low $\mathrm{CO}_{2}$ cement-based materials industry." United Nations Environment Program. 

153.https://doi.org/10.1016/j.cemconcomp.2012.11.004 Shimada, Y., and Young, J. F. (2004). "Thermal stability of ettringite in alkaline solutions at $80^{\circ} \mathrm{C}$." Cem. Concr. Res., 34, 2261-2268.https://doi.org/10.1016/j.cemconres.2004.04.008 60.2 test methods to determine ASR mitigation." Concrete 2019, Concrete in Practice-Progress through Knowledge Sydney, Australia.

591 Sirivivatnanon, V., Mohammadi, J., and South, W. (2016). "Reliability of new Australian test methods in predicting alkali silica reaction of field concrete." Construction and Building Materials, 126, 868874.https://doi.org/10.1016/j.conbuildmat.2016.09.055 Lothenbach, B. (2018). "Report of TC 238-SCM: hydration stoppage methods for phase assemblage studies of blended cements -results of a round robin test." Mater. Struct., 51(111).https://doi.org/10.1617/s11527-018$1237-5$ reactivity-Accelerated mortar bar method." Standards Australia. Standards Australia (2015). "Alkali Aggregate Reaction-Guidelines on Minimising the Risk of Damage to Concrete Structures in Australia." SAI Global Limited, Sydney, Australia. 693.https://doi.org/10.1016/S0008-8846(01)00466-5 

318.https://doi.org/10.1016/0008-8846(95)00219-7 Thomas, M. D. A. (2013). Supplementary Cementing Materials in Concrete, Taylor \& Francis Group, LLC, Boca Raton, Florida. Portland Limestone Cement." Concr. Int., 39-35 Thomson, V. E., Huelsman, K., and Ong, D. (2018). "Coal-fired power plant regulatory rollback in the United States: Implications for local and regional public health." Energy Policy, 123, 558-568 Tsivilis, S., Batis, G., Chaniotakis, E., Grigoriadis, G., and Theodossis, D. (2000). "Properties and behavior of limestone cement concrete and mortar." Cem. Concr. Res., 30(10), 1679-1683.https://doi.org/10.1016/S00088846(00)00372-0 Tsivilis, S., Tsantilas, J., Kakali, G., Chaniotakis, E., and Sakellariou, A. (2003). "The permeability of Portland limestone cement concrete." Cem. Concr. Res., 33(9), 1465-1471.https://doi.org/10.1016/S00088846(03)00092-9 and limestone powder to mitigate alkali-silica reaction risk." Constr. Build. Mater., 151, 422427.https://doi.org/10.1016/j.conbuildmat.2017.06.075 Voglis, N., Kakali, G., Chaniotakis, E., and Tsivilis, S. (2005). "Portland-limestone cements. Their properties and hydration compared to those of other composite cements." Cem. Concr. Compos., 27 191196.https://doi.org/10.1016/j.cemconcomp.2004.02.006

631 Vollpracht, A., Lothenbach, B., Snellings, R., and Haufe, J. (2016). "The pore solution of blended cements: a review." Mater. Struct., 49, 3341-3367 Wang, H., Wu, D., and Mei, Z. (2019). "Effect of fly ash and limestone powder on inhibiting alkali aggregate reaction of concrete." Constr. Build. Mater., 210, 620-626.https://doi.org/10.1016/j.conbuildmat.2019.03.219 
641

642

643

644

Table 1. XRF Oxide Composition of the raw materials

\begin{tabular}{|c|c|c|c|c|c|}
\hline Oxide wt.\% & $\begin{array}{c}\text { 0\% Limestone GP } \\
\text { Cement (OPC) }\end{array}$ & $\begin{array}{c}\text { Ground } \\
\text { Limestone }\end{array}$ & Fly Ash & Slag & Greywacke \\
\hline $\mathrm{SiO}_{2}$ & 20.36 & 1.30 & 59.21 & 34.12 & 66.85 \\
\hline $\mathrm{TiO}_{2}$ & 0.30 & 0.04 & 1.11 & 0.87 & 0.65 \\
\hline $\mathrm{Al}_{2} \mathrm{O}_{3}$ & 5.25 & 0.43 & 28.11 & 14.37 & 14.24 \\
\hline $\mathrm{Fe}_{2} \mathrm{O}_{3}$ & 3.06 & 0.21 & 3.68 & 0.30 & 3.80 \\
\hline $\mathrm{Mn}_{3} \mathrm{O}_{4}$ & 0.05 & 0.02 & 0.11 & 0.36 & 0.09 \\
\hline $\mathrm{MgO}$ & 1.35 & 0.36 & 0.53 & 5.31 & 1.58 \\
\hline $\mathrm{CaO}$ & 63.55 & 55.11 & 2.48 & 41.59 & 1.94 \\
\hline $\mathrm{Na}_{2} \mathrm{O}$ & 0.28 & 0.14 & 0.63 & 0.35 & 4.25 \\
\hline $\mathrm{K}_{2} \mathrm{O}$ & 0.40 & 0.06 & 1.18 & 0.26 & 3.11 \\
\hline $\mathrm{P}_{2} \mathrm{O}_{5}$ & 0.22 & 0.02 & 0.41 & 0.01 & 0.14 \\
\hline $\mathrm{SO}_{3}$ & 2.44 & 0.02 & 0.16 & 2.83 & 0.19 \\
\hline $\mathrm{Na}_{2} \mathrm{O}_{\text {eq }}$ & 0.54 & 0.18 & 1.41 & 0.52 & - \\
\hline $\mathrm{L} . \mathrm{O} . \mathrm{I}$ & 2.77 & 42.99 & 1.05 & 0.35 & 2.29 \\
\hline
\end{tabular}

645

646

647

648

649

Table 2. Greywacke Mineralogical Composition

\begin{tabular}{|l|l|}
\hline Mineral & $\%$ \\
\hline Microcrystalline feldspars & 37 \\
\hline Microcrystalline Quartz & 17 \\
\hline Quartz & 13 \\
\hline Epidote & 8 \\
\hline Moderately Strained Quartz & 7 \\
\hline Feldspar & 7 \\
\hline Lithic clasts & 5 \\
\hline Calcite & 3 \\
\hline Chlorite & 2 \\
\hline Sericite & 1 \\
\hline
\end{tabular}

Table 3. AS 1141.60.1 aggregate grading requirements

\begin{tabular}{|c|c|c|}
\hline \multicolumn{2}{|c|}{ Sieve size, $\mathrm{mm}$} & \multirow{2}{*}{$\begin{array}{c}\text { \% by } \\
\text { mass }\end{array}$} \\
\cline { 1 - 2 } Passing & Retained on & 10 \\
\hline 4.75 & 2.36 & 25 \\
\hline 2.36 & 1.18 & 25 \\
\hline 1.18 & 0.60 & 25 \\
\hline 0.60 & 0.30 & 15 \\
\hline 0.30 & 0.15 & \\
\hline
\end{tabular}


Table 4. AS 1141.60.1 aggregate reactivity classification

\begin{tabular}{|c|c|c|}
\hline \multicolumn{2}{|c|}{ Mean mortar bar expansion E, \% } & \multirow{3}{*}{$\begin{array}{l}\text { AS } 1141.60 .1 \text { aggregate } \\
\text { reactivity classification }\end{array}$} \\
\hline \multicolumn{2}{|c|}{ Duration of specimens in $1 \mathrm{M} \mathrm{NaOH}$ at $80^{\circ} \mathrm{C}$} & \\
\hline 10 days & 21 days & \\
\hline- & $E<0.10$ & Non-reactive \\
\hline$E<0.10$ & $0.10 \leq \mathrm{E}<0.30$ & Slowly reactive \\
\hline$E>0.10$ & - & Reactive \\
\hline- & $0.30 \leq \mathrm{E}$ & Reactive \\
\hline
\end{tabular}

652

653

Table 5. Elemental Analysis of the ASR Gel (normalized without oxygen). Data are quoted in atom \% (at\%)

\begin{tabular}{|c|c|c|c|c|c|c|c|c|c|}
\hline \multirow{2}{*}{$\begin{array}{c}\text { EDS } \\
\text { Location }\end{array}$} & \multicolumn{9}{|c|}{ at\% } \\
\hline & $\mathrm{Ca}$ & Al & Si & $\mathrm{Na}$ & $\mathrm{K}$ & $\mathrm{Na}+\mathrm{K}$ & $\mathrm{Ca} / \mathrm{Si}$ & $(\mathrm{Na}+\mathrm{K}) / \mathrm{Si}$ & Total \\
\hline ASR Gel Pt 1 & 14.59 & 1.20 & 65.27 & 18.48 & 0.45 & 18.93 & 0.22 & 0.29 & 100.00 \\
\hline ASR Gel Pt 2 & 19.29 & 0.70 & 61.46 & 17.41 & 1.13 & 18.55 & 0.31 & 0.30 & 100.00 \\
\hline ASR Gel Pt 3 & 18.88 & 0.79 & 62.86 & 16.19 & 1.28 & 17.47 & 0.30 & 0.28 & 100.00 \\
\hline ASR Gel Pt 4 & 16.87 & 1.55 & 66.63 & 13.30 & 1.65 & 14.95 & 0.25 & 0.22 & 100.00 \\
\hline ASR Gel Pt 5 & 14.67 & 1.16 & 62.02 & 21.72 & 0.43 & 22.15 & 0.24 & 0.36 & 100.00 \\
\hline Average & 16.86 & 1.08 & 63.65 & 17.42 & 0.99 & 18.41 & 0.26 & 0.29 & 100.00 \\
\hline Minimum & 14.59 & 0.70 & 61.46 & 13.30 & 0.43 & 14.95 & 0.22 & 0.22 & 100.00 \\
\hline Maximum & 19.29 & 1.55 & 66.63 & 21.72 & 1.65 & 22.15 & 0.31 & 0.36 & 100.00 \\
\hline
\end{tabular}

655 
657

660

661

662

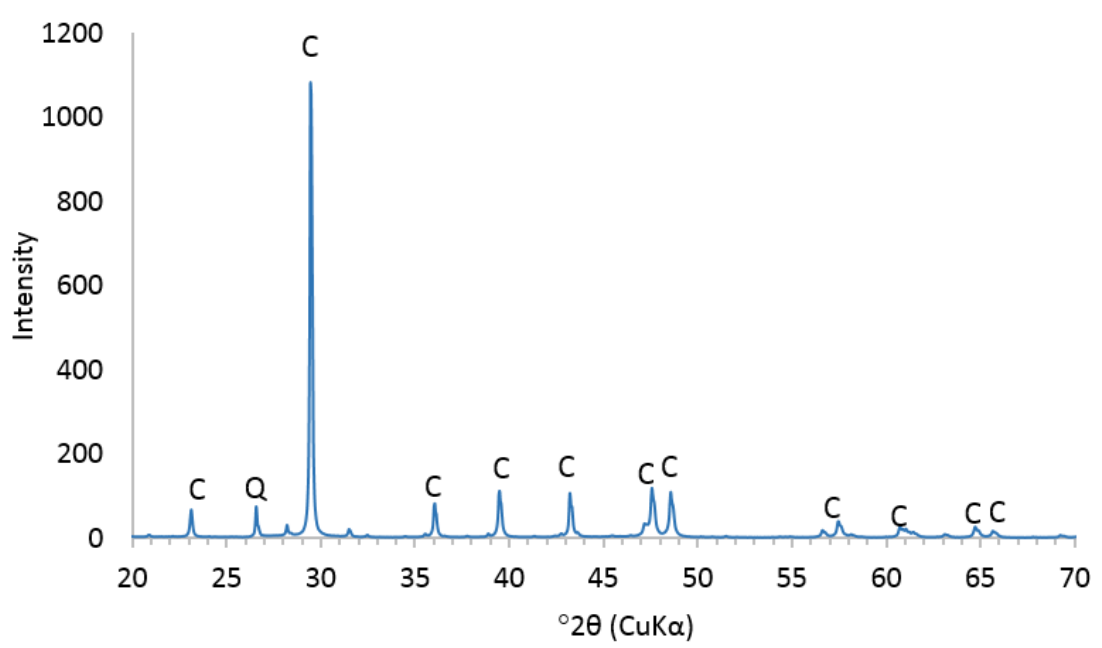

Fig.1. XRD pattern of ground limestone where $\mathrm{C}=$ calcite and $\mathrm{Q}=$ quartz

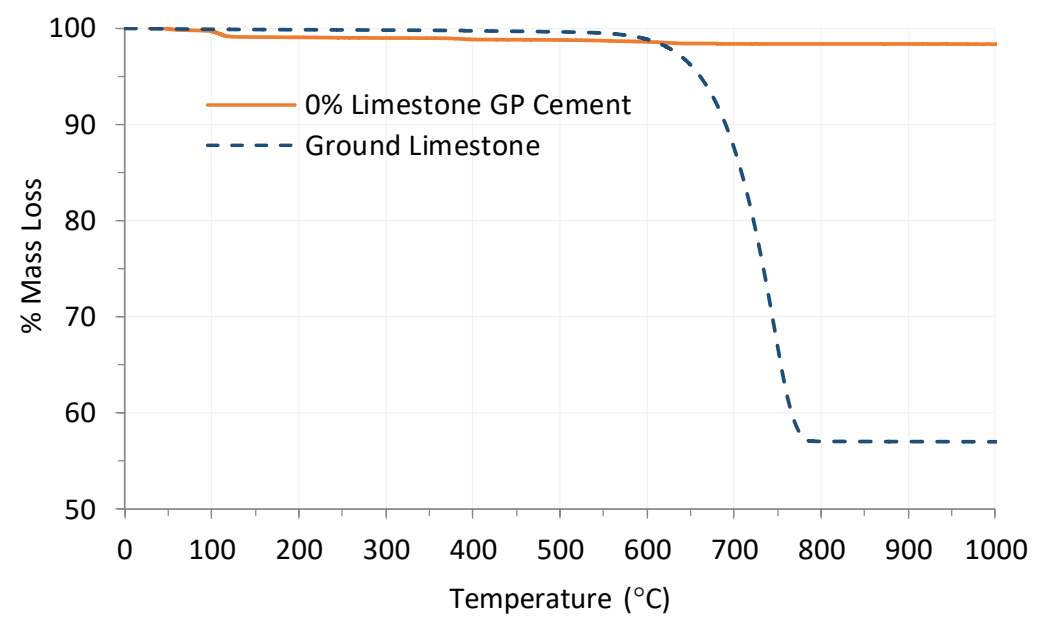

Fig.2. TG Curves of the GP cement and ground limestone 

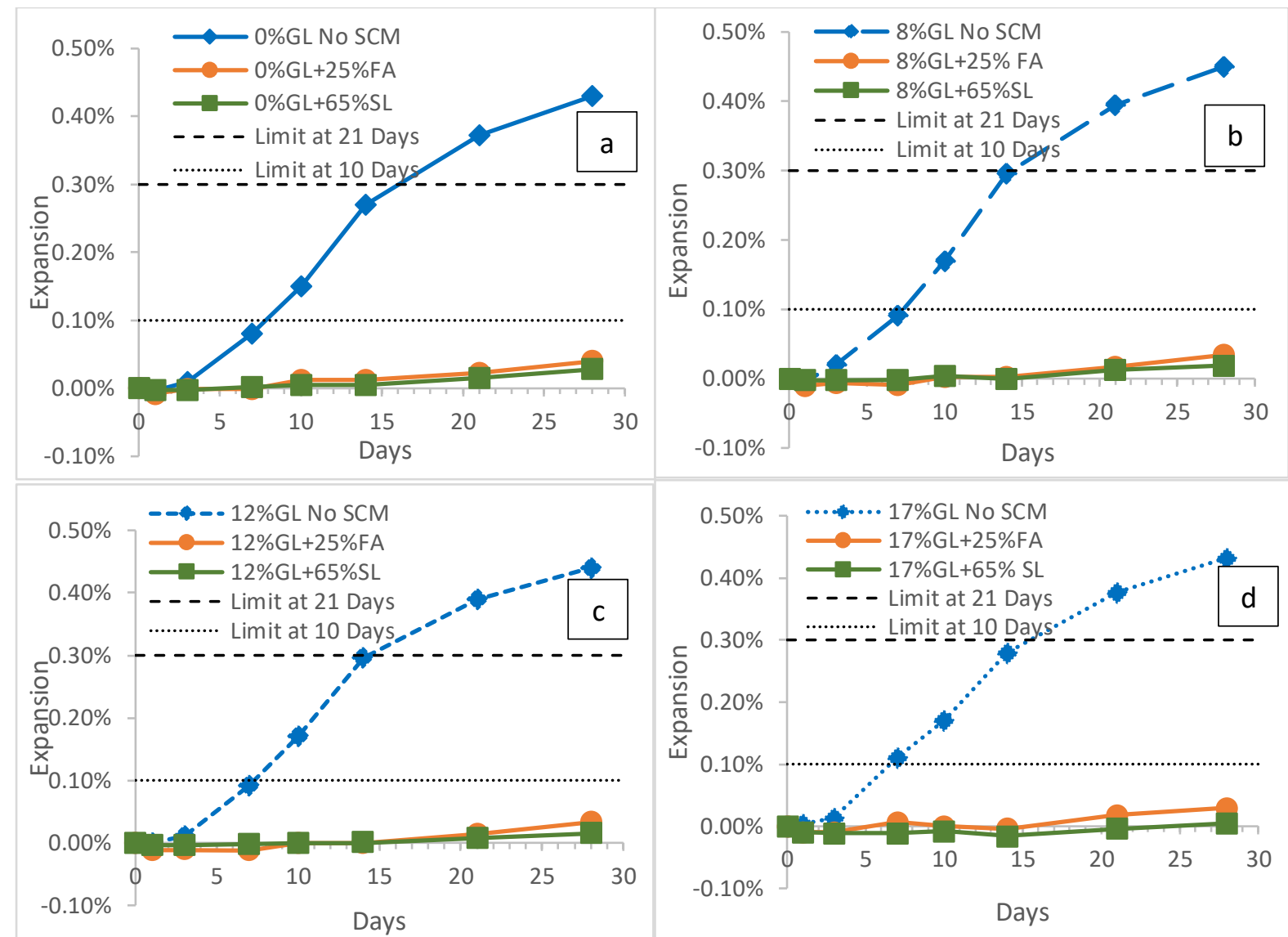

Fig.3. AMBT expansion results showing effect of SCM addition in binder systems with different limestone

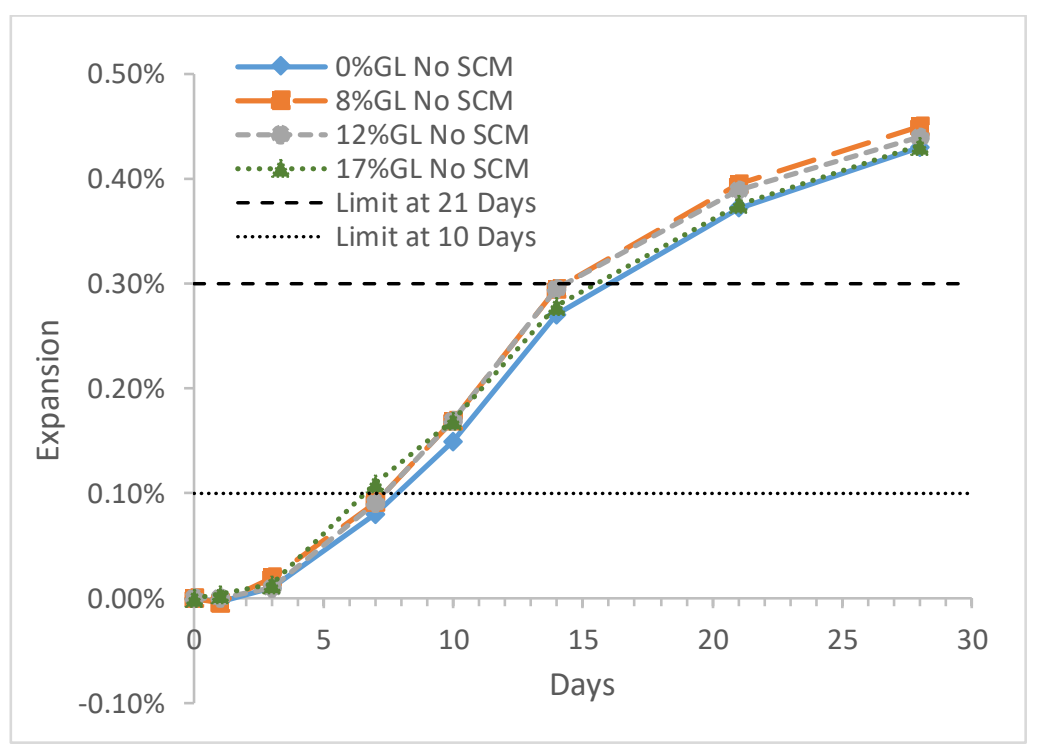



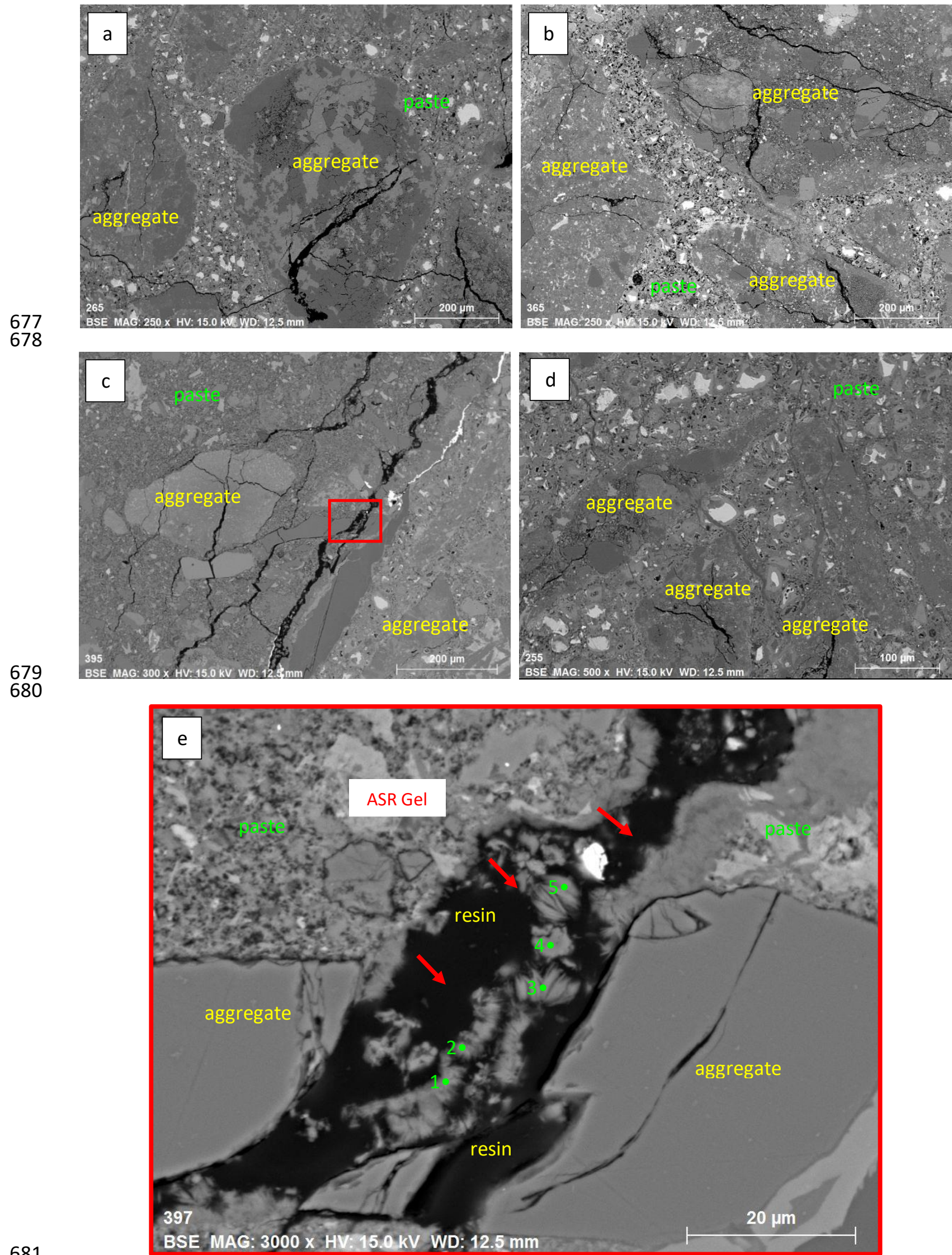

Fig.5. ASR Gel in greywacke mortar without SCM addition a) $0 \% \mathrm{GL}$, b) $8 \% \mathrm{GL}, \mathrm{c}$ ) $12 \% \mathrm{GL}$, d) $17 \% \mathrm{GL}$ and e) higher magnification image of ASR gel in $12 \% \mathrm{GL}$ mortar 

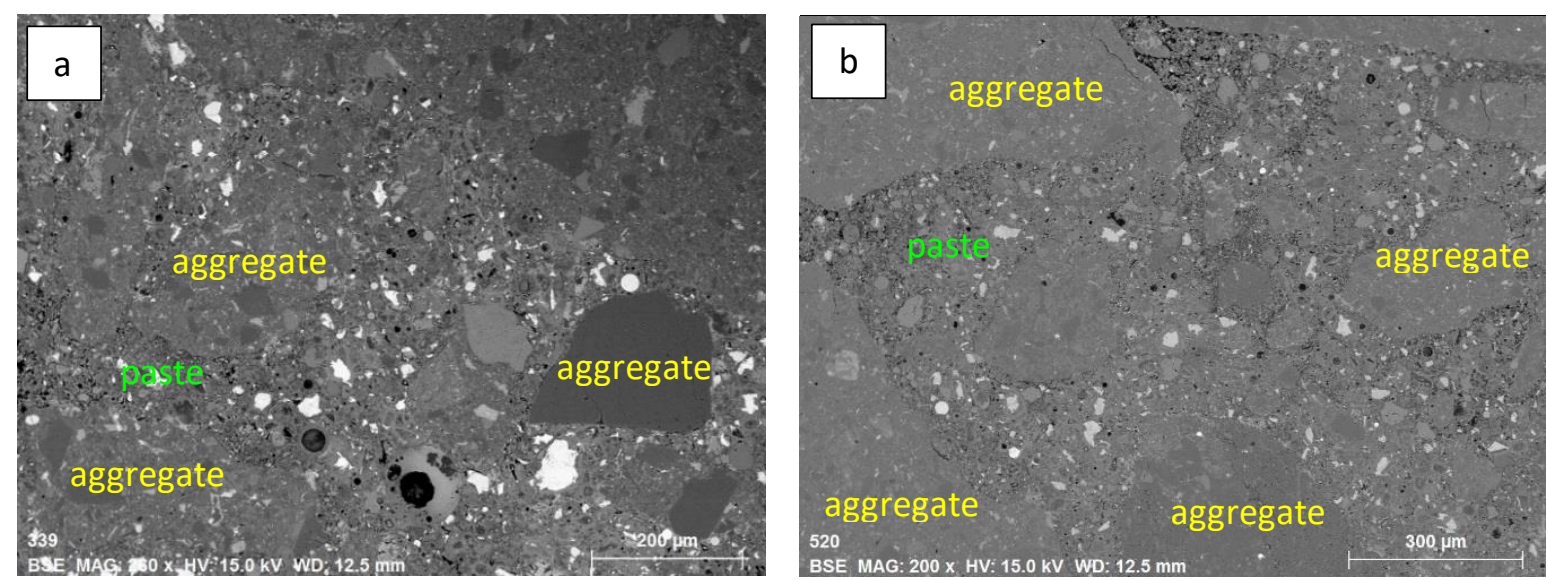

686
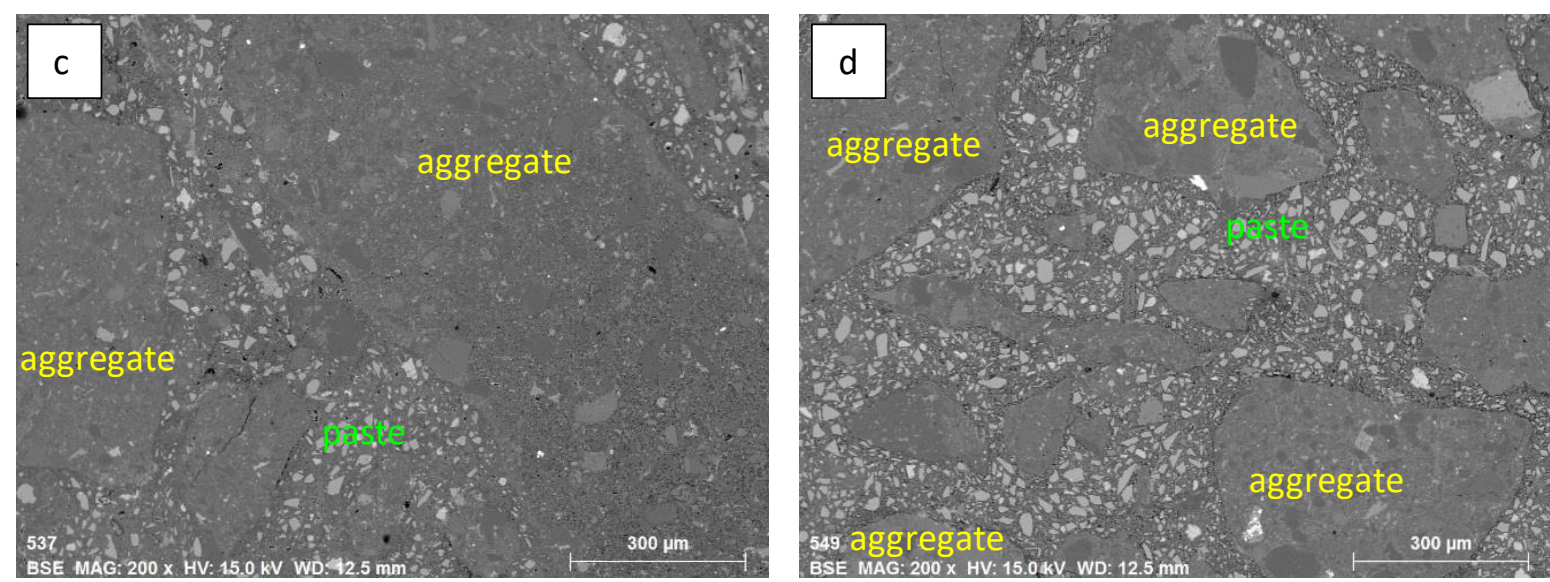

Fig.6. SEM image of the mortars a) $0 \% \mathrm{GL}+25 \% \mathrm{FA}$, b) $17 \% \mathrm{GL}+25 \% \mathrm{FA}$, c) $0 \% \mathrm{GL}+65 \% \mathrm{SL}$ and d) $17 \% \mathrm{GL}+65 \% \mathrm{SL}$ 

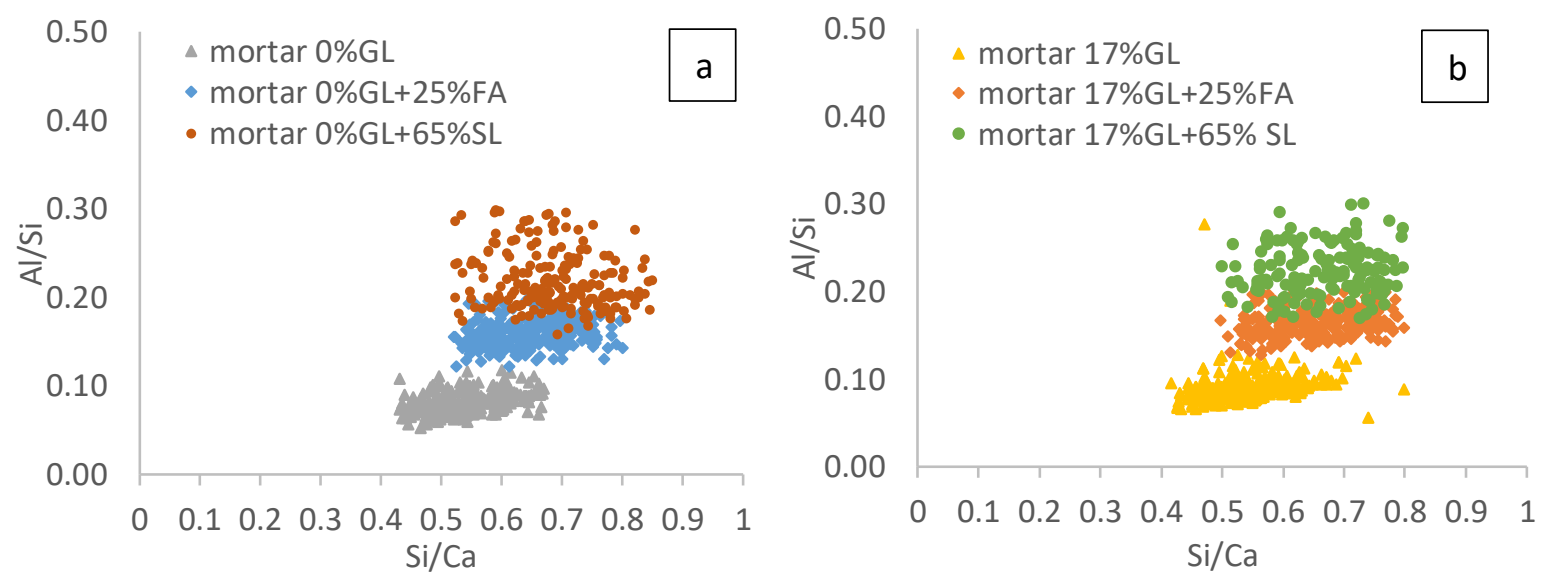

Fig.7. Effect of limestone content on $\mathrm{Si} / \mathrm{Ca}$ and $\mathrm{Al} / \mathrm{Si}$ ratio for mortars with a) $0 \% \mathrm{GL}$ and b) $17 \% \mathrm{GL}$

697

698

699

700

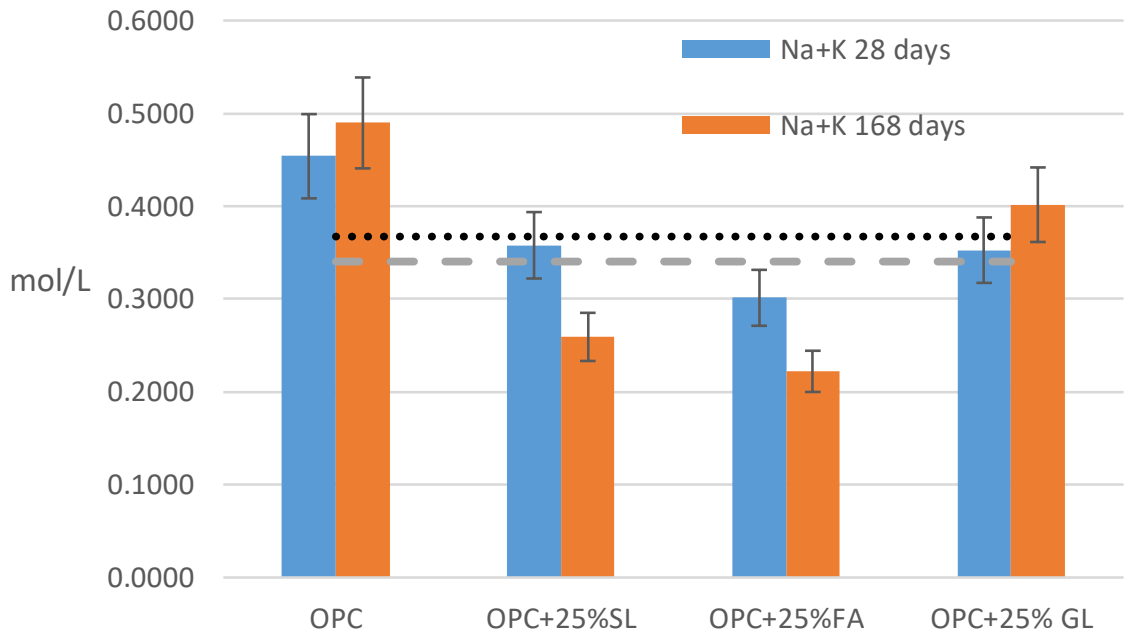

701

Fig.8. Effect of limestone, fly ash and slag on the pore solution alkali concentration 


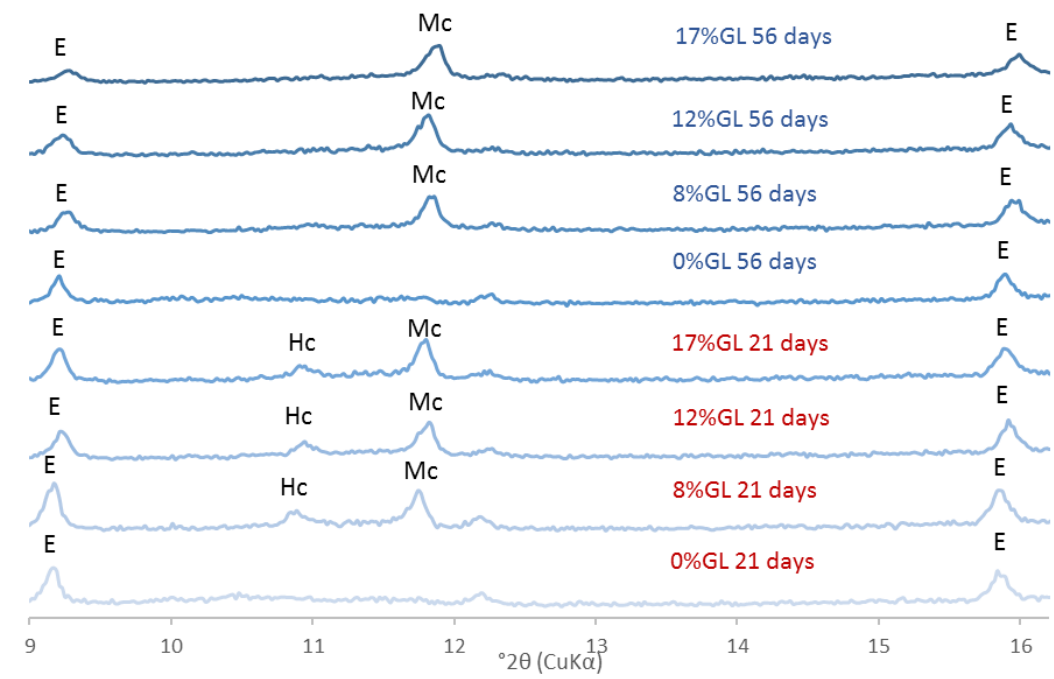

707

Fig.9. XRD patterns of limestone blended cement pastes without SCMs after 21 days and 56 days ageing at $90 \% \mathrm{RH}, 23 \pm 2{ }^{\circ} \mathrm{C}$ where $\mathrm{E}=$ ettringite, $\mathrm{Hc}=$ hemicarboaluminate and $\mathrm{Mc}=$ monocarboaluminate.
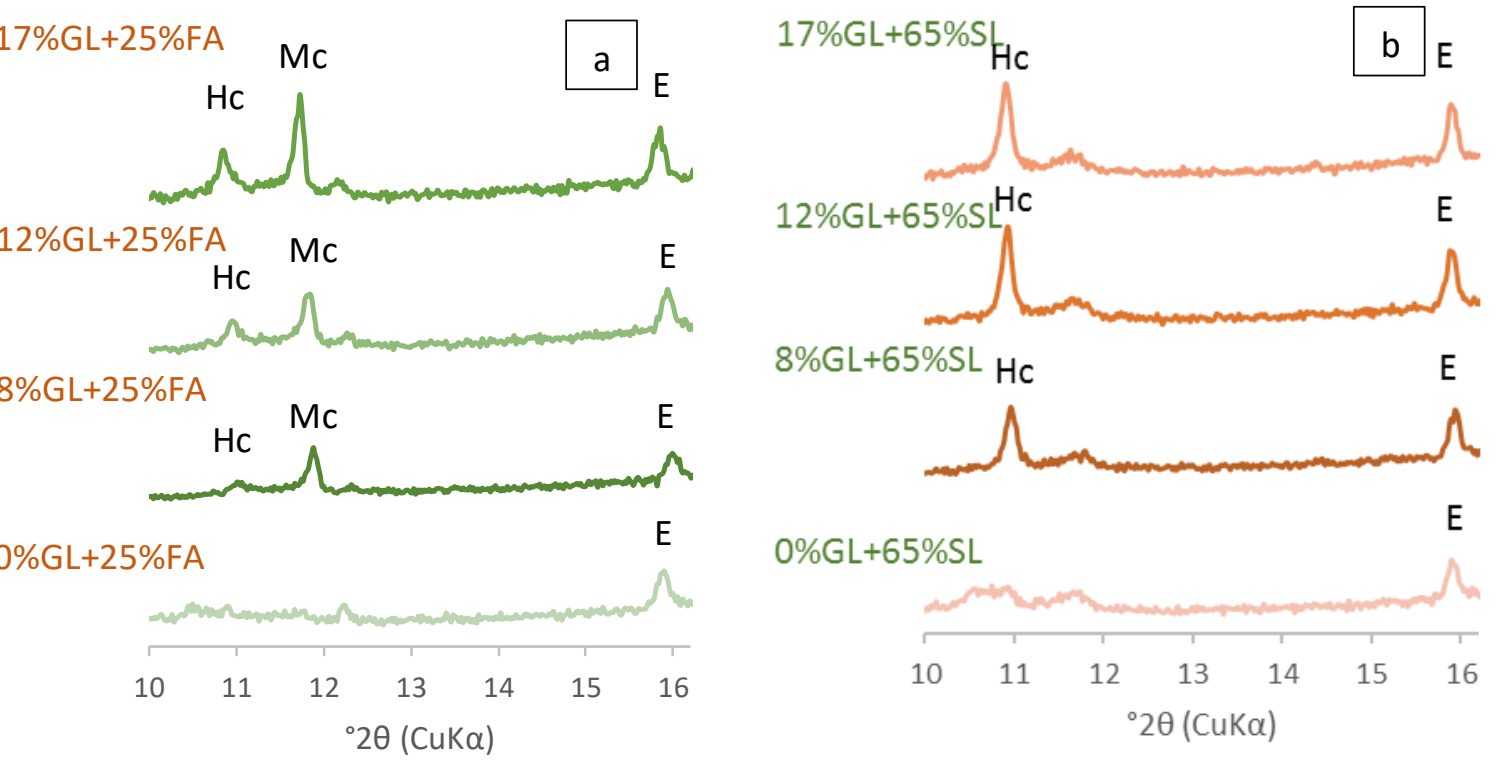

Fig.10. XRD patterns of a) $25 \%$ fly ash and b) $65 \%$ slag limestone blended cement pastes after 21 days ageing at $90 \% \mathrm{RH}, 23 \pm 2{ }^{\circ} \mathrm{C}$ where $\mathrm{E}=$ ettringite, $\mathrm{Hc}=$ hemicarboaluminate, and $\mathrm{Mc}=$ monocarboaluminate. 
21 days

17\%GLAMBT a

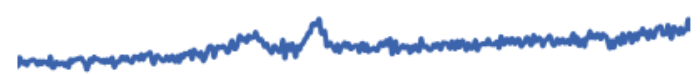

12\%GL AMBT

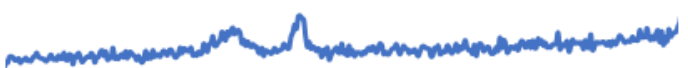

8\%GL AMBT

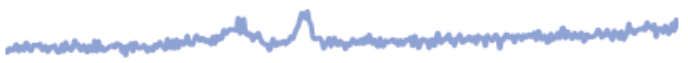

0\%GL AMBT
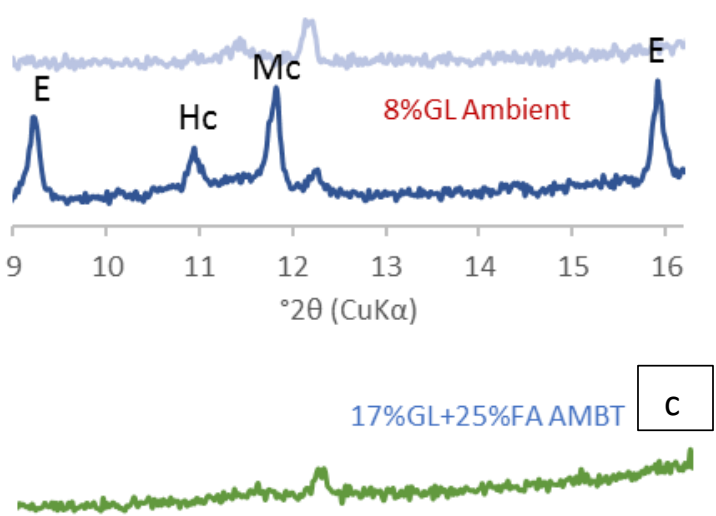

$12 \%$ GL $+25 \%$ FA AMBT

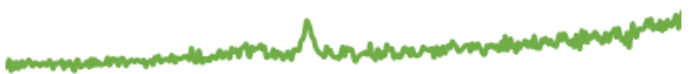

$8 \% \mathrm{GL}+25 \%$ FA AMBT
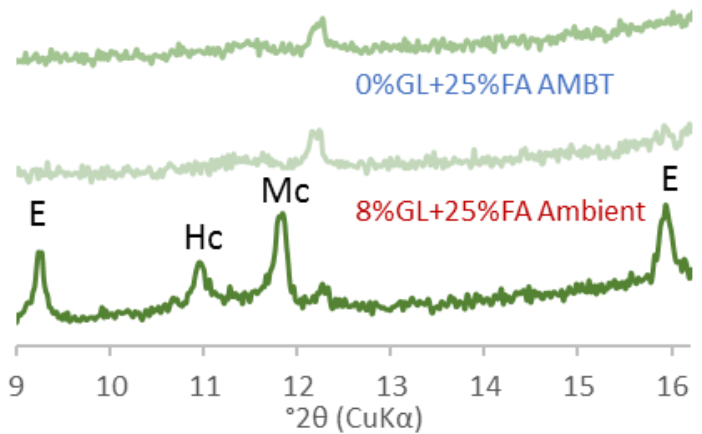

56 Days

17\%GLAMBT

$\mathrm{b}$

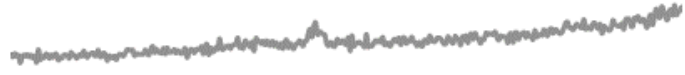

12\%GL AMBT

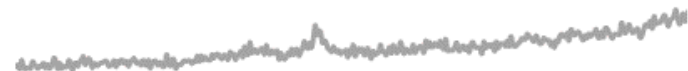

8\%GL AMBT

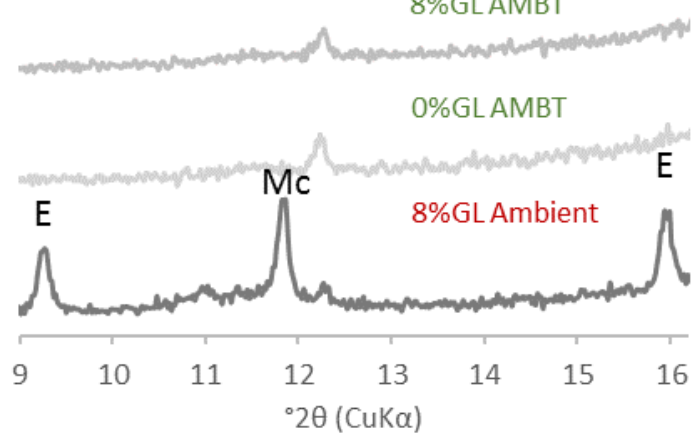

$17 \% \mathrm{GL}+65 \% \mathrm{SL}$ AMBT

d
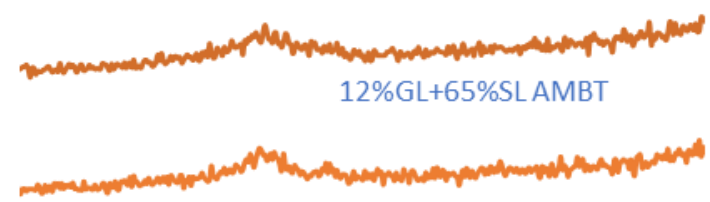

$8 \% G L+65 \%$ SL AMBT

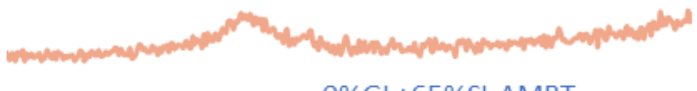

$0 \% G L+65 \%$ SL AMBT

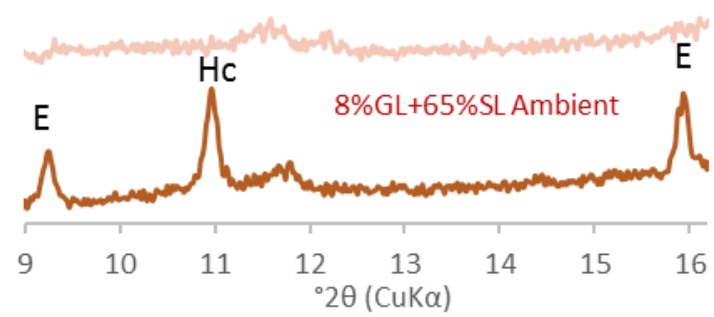

Fig.11. Effect of AMBT conditions $\left(1 \mathrm{M} \mathrm{NaOH} 80^{\circ} \mathrm{C}\right)$ on ettringites and carboaluminates for: a) cement paste at 


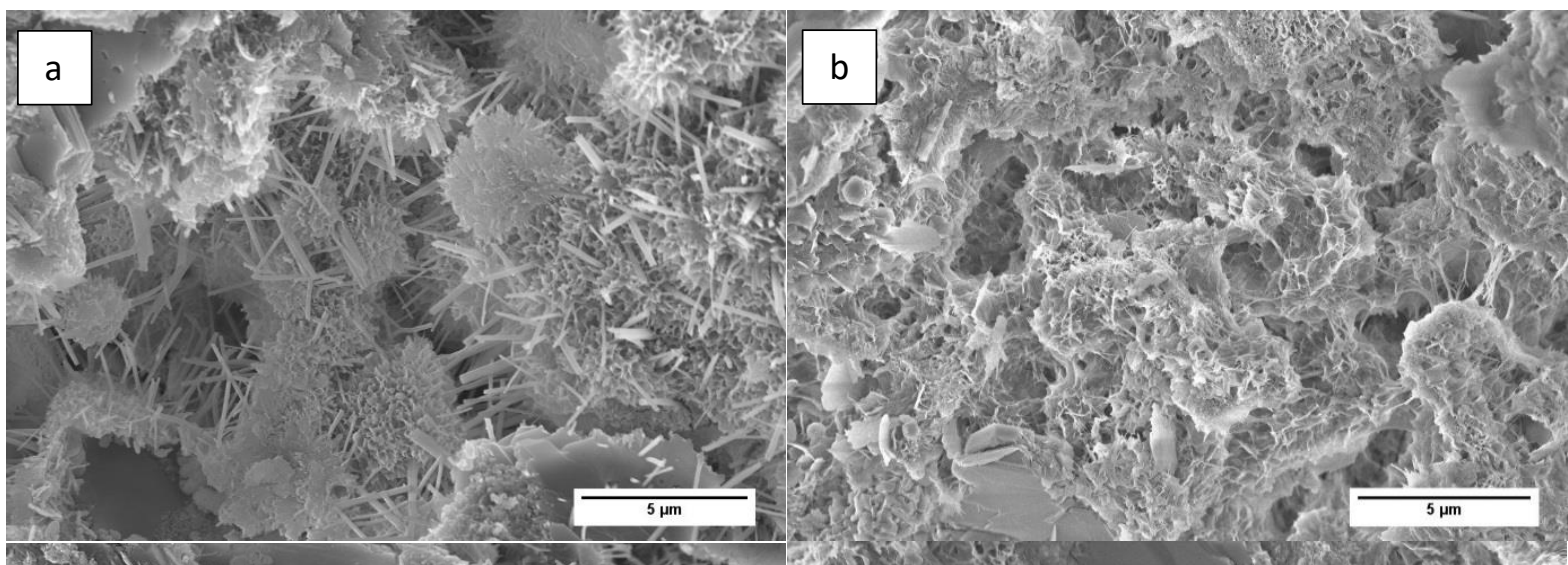

723

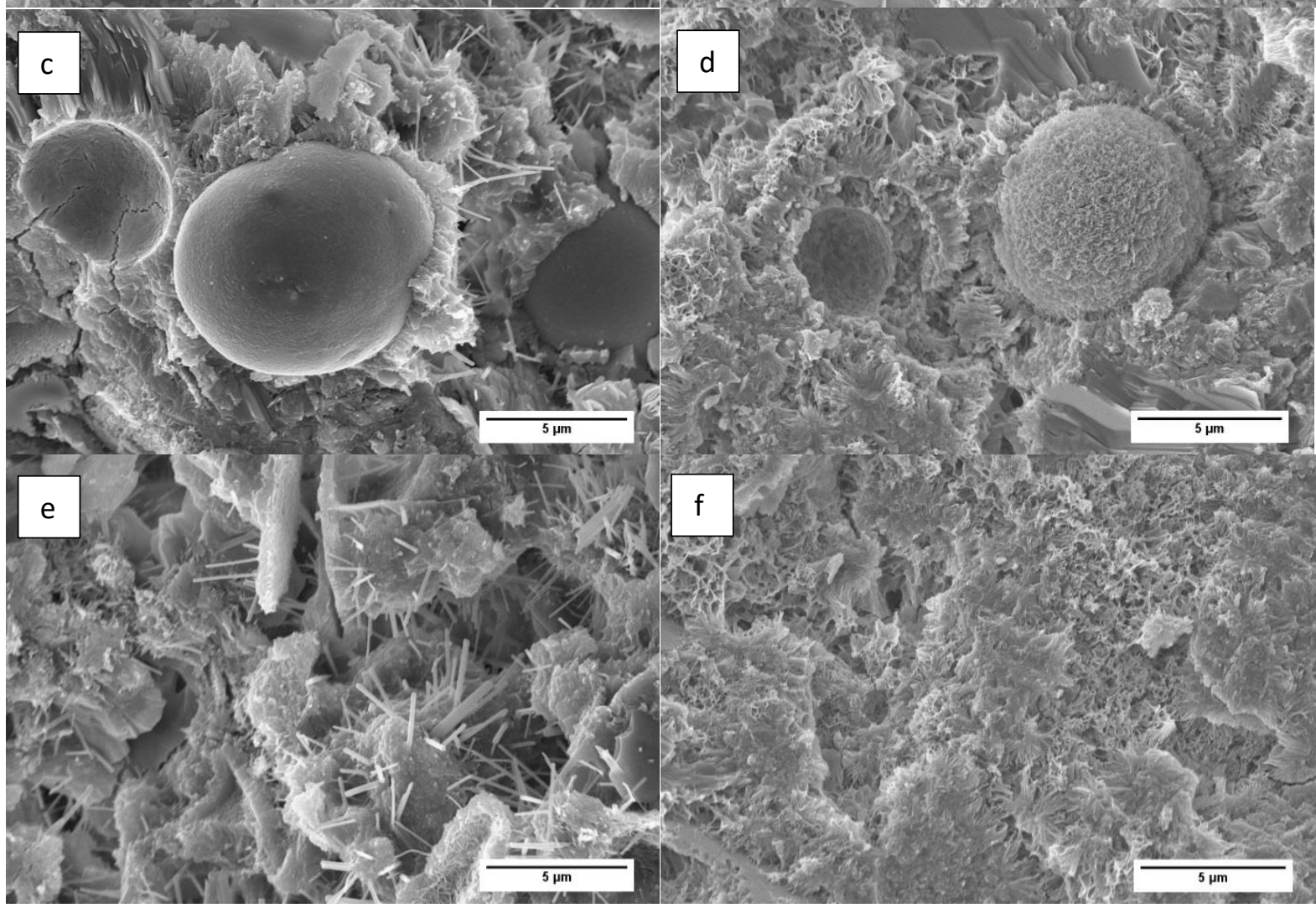

724

725

726

727

728

729

730

Fig.12. SEM images of cement+ $8 \% \mathrm{GL}$ without SCM after 21 days a) $90 \% \mathrm{RH} 23 \pm 2{ }^{\circ} \mathrm{C}$ curing and b) exposure to AMBT conditions $\left(1 \mathrm{M} \mathrm{NaOH} 80^{\circ} \mathrm{C}\right)$, cement $+8 \% \mathrm{GL}+25 \% \mathrm{FA}$ after 21 days $\left.\mathrm{C}\right) 90 \% \mathrm{RH} 23 \pm 2{ }^{\circ} \mathrm{C}$ curing and d) exposure to $A M B T$ conditions $\left(1 \mathrm{M} \mathrm{NaOH} 80^{\circ} \mathrm{C}\right)$ and cement+8\%GL+65\% SL after 21 days e) $90 \% \mathrm{RH} 23 \pm 2{ }^{\circ} \mathrm{C}$ curing f) exposure to $A M B T$ conditions $\left(1 \mathrm{M} \mathrm{NaOH} 80^{\circ} \mathrm{C}\right)$. 